\title{
Grazing systems and the control of vegetation dynamics in Reunion island (Indian Ocean)
}

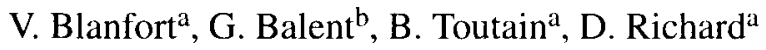 \\ ${ }^{a}$ CIRAD EMVT, BP 5035, 34032 Montpellier cedex 1 ; ${ }^{b}$ Inra-URSAD/SEBSO, 31326 \\ Castanet-Tolosan cedex, France
}

For 20 years, on the Reunion island, development plans work towards the stabilisation of the rural population through sustainable agriculture. The grazing systems are an essential component of these volcanic highlands (1000-2000 m). In an insular context $\left(2500 \mathrm{~km}^{2}\right)$, intensification is necessary for the development of animal production. However, the benefits of livestock farming from social and touristic points of view must be considered as well as the management of these fragile and original ecosystems. Year-round rotational grazing on native and sown pastures contribute to their sustainability and their profitability. The control of quality and quantity of grass through the year is the main short-term problem for the breeders. The durability of species composition concerns a more long time scale forage and landscape management. Diagnosis tools and decision rules were build up for a sustainable control of these ecosystems. We analyse the relationship between the vegetation dynamics and the agricultural practices through three indicators measured in 100 paddocks in six cattle farms. Both sward-height and available herbage volume show poor relationships between management practices and the seasonal rhythm of grass growth. The mineral composition of vegetation indicates that fertilising practices are not well adapted to the volcanic nature of soil (especially phosphorous availability). Some management practices seem to lead to a non-reversible degradation stage of the vegetation (Ulex europeus is one of the degradation species).

\section{Caractérisation de l'évolution des exploitations d'élevage Blanc-Bleu-Belge en relation avec l'évolution de la $\mathbf{P A C}$}

\author{
D. Stilmant ${ }^{\mathrm{a}}$, Ph. Lecomte ${ }^{\mathrm{a}}$, L. Fabry ${ }^{\mathrm{b}}$ \\ ${ }^{a}$ CRAGx, 100, rue du Serpont, 6800 Libramont ; ${ }^{b}$ APEDB, 41, rue de la Clef, 4650 Herve, \\ Belgique
}

L'évolution technico économique d'exploitations du Sud-Est Belge tirant plus de $80 \%$ de leurs revenus de la production de viande bovine a été analysée de 1984 à 1996. L'analyse s'appuye sur le suivi de 135 exploitations * années. La rentabilité maximum de la spéculation se situe fin des années 80. À cette époque ces exploitations abandonnèrent les cultures commerciales pour se spécialiser dans l'élevage. Parallèlement, la surface fourragère est passée de $80 \%$ de la SAU en 1984 à $90 \%$ en 1987 , ce qui, couplé à une augmentation de $20 \%$ de la SAU par unité de main d'œuvre, a permis une évolution de la taille des cheptels de $35 \%$ entre 1984 et 1990. Mais, dès 1990 le secteur de la viande bovine a accusé un net recul au niveau de ses revenus, recul qui s'est accentué jusqu'en 1996. Afin de maintenir leurs revenus, les éleveurs augmentent encore la taille de leur cheptel $(+31 \%$ entre 1993 et 1996). Parallèlement, ils augmentent leur SAU (+ $24 \%$ entre 1990 et 1996) afin de bénéficier des primes nécessitant de descendre sous les $2 \mathrm{UGB} \cdot \mathrm{ha}^{-1}$. Cette double démarche a un impact très important sur le prix de la terre agricole qui dans notre région a été jusqu'à doubler localement. La désintensification ainsi obtenue permet également une meilleure couverture des besoins alimentaires à partir des fourrages produits sur l'exploitation ( $76 \%$ en 1996 contre $68 \%$ en 1984), malgré une fertilisation azotée qui a chuté de plus de $25 \%$ depuis 1990. 